\title{
Pengaruh Otonomi Daerah Dalam Percepatan Penanganan Covid-19
}

\author{
Dewi Oktaviyanti (1) \\ Devi Aprilia ${ }^{(2)}$ \\ Romadhoni Usflida Sari (3) \\ Safitri Nur Rohmah ${ }^{(4)}$ \\ Wahyu Adhi Saputro ${ }^{(5)}$
}

Universitas Duta Bangsa Surakarta ${ }^{(12345)}$

safitrifitri1901@gmail.com ${ }^{(4)}$

\begin{abstract}
In the current condition, the Covid-19 pandemic has an impact that is enough to make everyone feel distress until the government really carries out regional autonomy appropriately. The Covid-19 pandemic is not over and causes a lot of adversity, especially for the community both in terms of income and social aspects. This study aims to 1) analyze the regional policies that have been applied in dealing with a pandemic 2) Look at the influence of local policies on the socio-economic conditions of the community. The method used in this study is the analytical descriptive method approach. The data used are analytic qualitative data and literature literature study. Based on the results and discussion in this study, regional autonomy policy allows regional governments to freely apply large-scale social restrictions with quarantine or temporary lockdown in order to stop covid-19 transmission. Local government policy has a significant influence on the handling of Covid19 due to the potential potential of workers who stop working as much as $16 \%$ so that the government reopens economic places such as the market as an effort to improve the economy and the welfare of the community who are sinking while continuing to implement health protocols.
\end{abstract}

Keywords: Covid-19; Regional Autonomy; Policy

\begin{abstract}
ABSTRAK
Dalam kondisi saat ini, pandemi Covid-19 memberikan dampak yang cukup membuat semua merasakan kesusahan hingga pemerintah benar-benar melakukan otonomi daerah dengan tepat.Pandemi Covid-19 belum usai dan menyebabkan banyak sekali keterpurukan khususnya bagi masyarakat baik dari segi pendapatan maupun segi sosial. Penelitian ini bertujuan untuk menganalisis dan melihat pengaruh kebijakan daerah yang telah diterapkan dalam menangani pandemi terhadap kondisi sosial ekonomi masyarakat. Metode yang digunakan dalam penelitian ini yaitu dengan pendekatan metode desktipti analitis. Data yang digunakan merupakan data kualitatif analitik dan studi pustaka literatur. Berdasarkan hasil dan pembahasan dalam penelitian ini kebijakan daerah secara otonomi membuat pemerintah daerah bisa leluasa dalam menerapkan pembatasan sosial berskala besar dengan karantina ataupun lockdown sementara agar menghentikan penularan covid-19. Kebijakan pemerintah daerah memiliki pengaruh yang signifikan terhadap penanganan Covid-19 dikarenakan adanya potensi potensi pekerja yang berhenti kerja sebanyak $16 \%$ sehingga pihak pemerintah membuka kembali tempat-tempat perekonomian seperti pasar sebagai upaya peningkatan perekonomian dan kesejahteraan masyarakat yang sedang terpuruk dengan tetap menerapkan protokol kesehatan.
\end{abstract}

Kata kunci: Covid-19; Otonomi Daerah; Kebijakan 


\section{PENDAHULUAN}

Corona virus merupakan sebuah virus jenis baru yang menyebabkan penyakit pada hewan maupun manusia. Virus ini menyebabkan infeksi saluran pernafasan pada manusia dari batuk ringan hingga Middle East Respiratory Syndrom (MERS) dan Severe Acute Respiratory Syndrome (SARS). Otonomi daerah merupakan pendelegasian kewenangan dan kebijakan pemerintah pusat kepada daerah untuk mengatur daerahnya, mendekatkan sebagian besar urusan pemerintahan untuk dikelola secara baik serta menangani suatu krisis dalam kerangka melaksanakan tugas pemerintah pusat di daerah.

Pembangunan nasional yang telah dilaksanakan lebih dari setengah abad di Indonesia telah memberikan hasil yang cukup siginifikan. Salah satu ukuran keberhasilan pembangunan nasional adalah meningkatnya pendapatan nasional (gross domestic product, GDP) atau pun GDP/perkapita (Nurwibowo dkk, 2013). Pendapatan Regional Per Kapita Per Tahun atas harga konstan tahun 2000 di Provinsi Jawa Tengah tahun 2010 sebesar Rp. 4.936.103,73, sedangkan untuk Pendapatan Regional Bruto Per Kapita Per Tahun sebesar Rp. 5.774.556,44. (BPS Jawa Tengah,2011). Namun dengan adanya pandemi Covid-19 memberikan hal yang berbeda dengan penurunan pendapatan baik pendapatan perkapita maupun pendapatan nasional.

Indonesia telah mengalami krisis ekonomi yang menyebabkan jatuhnya perekonomian nasional (Ananda dan Susilowati, 2019). Keberadaan UMKM tidak dapat dihapuskan ataupun dihindarkan dari masyarakat bangsa saat ini. Karena keberadaannya sangat bermanfaat dalam hal pendistribusian pendapatan masyarakat. Selain itu juga mampu menciptakan kreatifitas yang sejalan dengan usaha untuk mempertahankan dan mengembangkan unsur-unsur tradisi dan kebudayaan masyarakat setempat (Anggraeni dkk, 2011). Akan tetapi pandemi ini seolaholah membuat daya beli konsumen turun sehingga daya jual dari UMKM ikut menurun juga.

Raharja dan Manurung (2010:266) bahwa pendapatan merupakan total penerimaan berupa uang maupun bukan uang oleh seseorang atau rumah tangga selama periode tertentu. Kondisi sosial ekonomi masyarakat di Indonesia baik di perkotaan maupun di pedesaaan mengalami beberapa perubahan seiring dengan perkembangan jaman dan setelah masa krisis. Perubahan-perubahan terjadi untuk pemulihan dan perbaikan perekonomian (Iskandar, 2017). Namun setelah adanya pandemi ini agaknya sudah menuju ke arah masa kritis dimana banyak pekerja yang dirumahkan sehingga tidak mendapatkan pendapatan tetap di setiap bulannya. Dikhawatirkan akan muncul banyak kemiskinan akibat permasalah ini sehingga membuat angka kemiskinan meningkat. Berdasarkan uraian pada paragraph-paragraf sebelumnya 
penelitian ini ingin menganalisis dan mengetahui pengaruh kebijakan daerah yang telah diterapkan dalam menangani pandemi terutama bagi kondisi sosial-ekonomi masyarakat.

\section{Covid 19}

Dalam kondisi saat ini, wabah virus corona menyebabkan pandemi yang terjadi di seluruh negara yang ada. Kita tidak bisa menganggap Covid-19 ini sebagai wabah sepele. Jika dilihat dari gejalanya memang terlihat sederhana, masyarakat mungkin menganggapnya hanya influenza biasa, tetapi menurut analisis kedokteran virus ini sangat berbahaya dan mematikan (WHO, 2019).

\section{Otonomi Daerah}

Otonomi daerah adalah hak, wewenang serta kewajiban daerah dalam mengurus wilayahnya sendiri sesuai peraturan perundangan yang berlaku (Simanjuntak, 2010).

\section{METODE PENELITIAN}

Semua daerah di Indonesia menerima dampak parah akibat adanya Covid-19. Salah satu daerah yang menerima dampak tersebut adalah Kecamatan Gatak. Setiap wilayah memiliki kebijakan masing-masing dalam melakukan penanganan pandemi khususnya dari segi sosial ekonomi masyarakatnya. Populasi dalam penelitian ini adalah semua warga negara Indonesia. Sampel dalam penelitian ini adalah warga Kecamatan Gatak yang menerima pengaruh langsung dari kebijakan otonomi daerah. Metodologi yang digunakan dalam penelitian ini adalah deskriptif analitik. Data yang digunakan adalah data kualitatif dan kuantitatif. Sumber data berasal dari data primer para warga Kecamatan Gatak dan data sekunder dari sumber sumber yang relevan dan terpercaya. Metode pendekatan data kualitatif dan studi pustaka yaitu dengan mengumpulkan data-data serta mencari referensi untuk mendapatkan informasi yang valid. Informasi maupun data-data didapat melalui pengajuan pertanyaan atau aspirasi masyarakat apa yang dikeluhkan dengan adanya kebijakan tersebut. Dengan demikian, data yang sudah terkumpul akan dilakukan kajian untuk menerapkan kebijakan yang baru. Selanjutnya analisis berdasarkan kebijakan yang sudah diterapkan apakah memiliki pengaruh signifikan terhadap segi perekonomian maupun tingkat penyebaran virus Covid-19. 


\section{HASIL DAN PEMBAHASAN}

Saat ini perkembangan penyebaran virus corona meningkat cukup signifikan terutama di Indonesia. Penyebaran virus ini menyebabkan dampak bagi seluruh wilayah di Indonesia, sehingga membuat masing-masing daerah memiliki kewenangan untuk menggunakan hak otonomi daerahnya. Otonomi daerah merupakan kewenangan suatu daerah untuk mengatur sendiri kepentingan masyarakat atau kepentingan untuk menentukan kebijakan apa yang akan diambil.

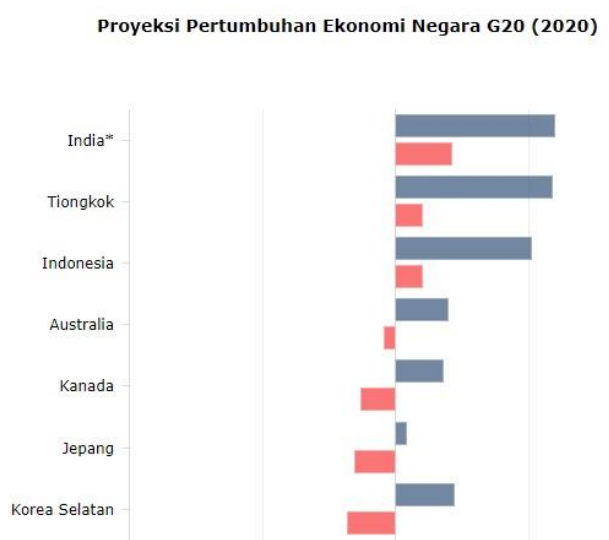

Gambar 1. Proyeksi Pertumbuhan Ekonomi

Sumber : Economist Intelligence Unit, 2020

Berdasarkan gambar 1 mengenai proyeksi pertumbuhan ekonomi di beberapa negara seperti India, Tiongkok, Indonesia, Australia, Kanada, Jepang, dan Korea Selatan. Semula memang pertumbuhan di beberapa negara berwarna biru sebelum terdampak covid-19 sehingga pertumbuhan masih bernilai positif. Akan tetapi dalam beberapa bulan ke depan jika kebijakan masing-masing negara tidak tepat dalam penanganan wabah tersebut maka pertumbuhan melambat dan cenderung negatif. Apalagi di Indonesia penduduknya sangat padat sehingga sangat mudah tertular.

\section{Analisis kebijakan daerah yang telah diterapkan dalam menangani pandemi}

Perkembangan kasus Covid-19 di berbagai wilayah Indonesia terutama di tingkat Kecamatan Gatak meningkat cukup signifikan. Hal ini membuat pemerintah daerah menekan kebijakan untuk pencegahan penyebaran yang semakin luas. Terkait pencegahan ini, pemerintah Kecamatan Gatak menerapkan kebijakan sosial distancing sesuai kebijakan pemerintah pusat. Kebijakan ini diterapkan karena penularan Covid-19 sangat cepat dengan gejala seperti influenza biasa. Oleh karena itu, siapapun ynag merasa sakit harus segera melakukan pemeriksaan ke pelayanan kesehatan terdekat. Di Kecamatan Gatak sendiri sampai saat ini masih nol kasus positif Covid-19, tetapi juga ada pasien ODP maupun PDP. 
Penerapan kebijakan lanjutan yaitu dengan kebijakan pemberlakuan lockdown di sebagian desa di Kecamatan Gatak. Kebijakan ini dinilai kurang efektif bagi sebagian masyarakat karena mereka merasa pergerakan mereka dibatasi, padahal mereka keluar untuk mencari nafkah. Mayoritas masyarakat yang tinggal di wilayah Kecamatan Gatak merupakan kelas ekonomi menengah ke bawah sehingga mau tidak mau harus tetap bekerja demi menyambung hidup.

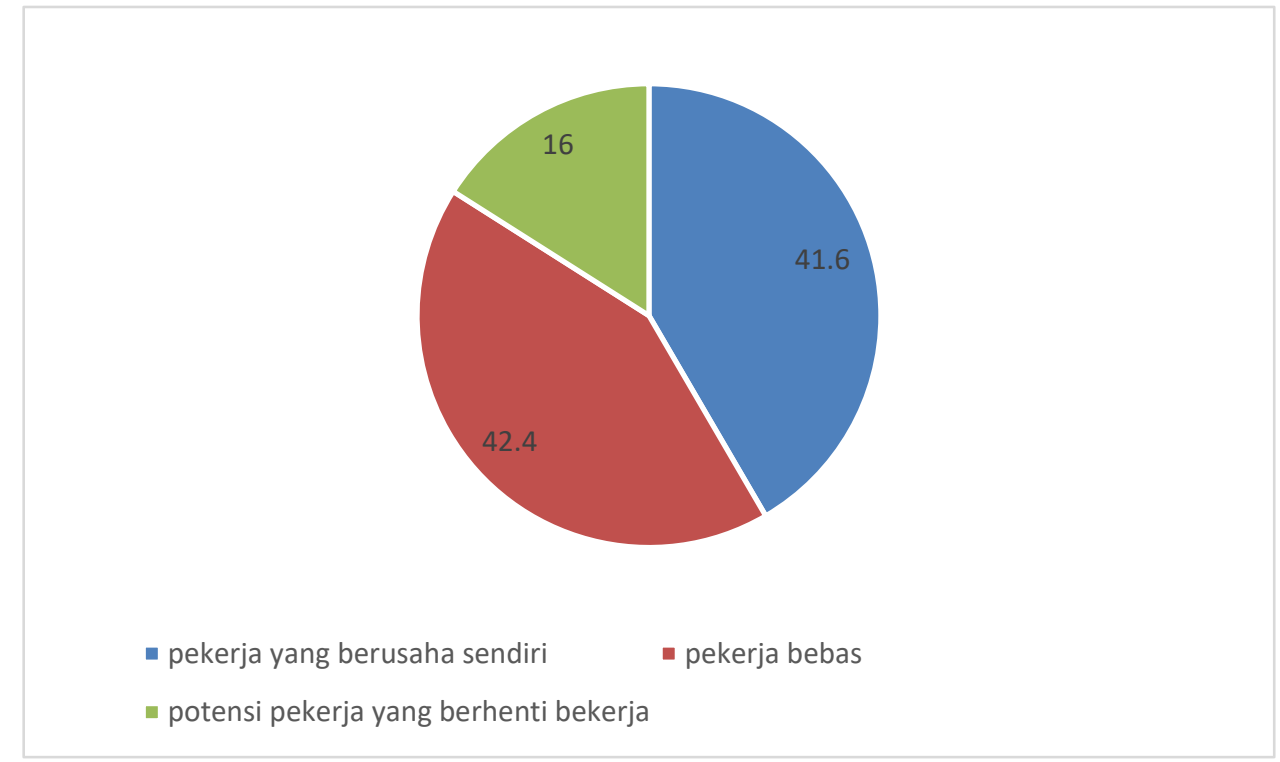

Gambar 2. Potensi Pekerja Yang Di Rumahkan

Sumber : Analisis Data Sekunder, 2020

Berdasarkan gambar 2 dapat diketahui sebanyak 16\% warga yang memiliki potensi pekerja yang dirumahkan atau diberhentikan dari pekerjaannya. Hal ini dikarenakan perusahaan mengalami pailit dikarenakan daya beli masyarakat yang turun serta diiringin dengan ketidak mampuan perusahaan dalam menjual produknya dalam kualitas dan kuantitasnya yang berlebih. Namun dengan begitu akan ada penamnbahan pekerja yang bekerja dengan usaha sendiri atau dapat dikatakan membuka pekerjaan sebanyak 41,6\% dengan cara berdagang dan lainnya. Contohnya saja di Kecamatan Gatak banyak beberapa orang yang berjualan masker, hand sanitizer dan lainnya yang menyangkut untuk mengurangi penularan covid-19. Hal ini sangat positif untuk menumbuhkan pendapatan daerah.

Antisipasi dan pencegahan penyebaran Covid-19 untuk mengurangi pasien yang positif Covid-19 di Kecamatan Gatak terus dilakukan. Upaya yang dilakukan diantaranya seperti: membatasi aktifitas di luar rumah, memakai masker ketika berpergian, rajin mencuci tangan. Dalam kebijakan ini tentunya sudah sesuai dengan kebijakan yang diambil oleh pemerintah pusat. 
Di tengah meningkatnya tingkat penyebaran virus corona di berbagai daerah hingga menyebabkan daerah tertentu menjadi zona merah Covid-19, Kecamatan Gatak menjadi salah satu peta penyebaran yang nol pasien positif Covid-19 (zona kuning) di Kabupaten Sukoharjo dengan berbagai upaya pencegahan yang dilakukan. Kondisi saat ini, tentunya banyak dampak yang dirasakan masyarakat terutama dalam bidang ekonomi. Banyak masyarakat di kecamatan Gatak yang terkena PHK di pekerjaan sebelumnya, banyak pelaku UMKM mengalami penurunan pendapatan. Dalam hal ini, lingkup pemerintah kecamatan Gatak melakukan peningkatan untuk pelaku UMKM agar terus berjalan meskipun sedikit menurun.

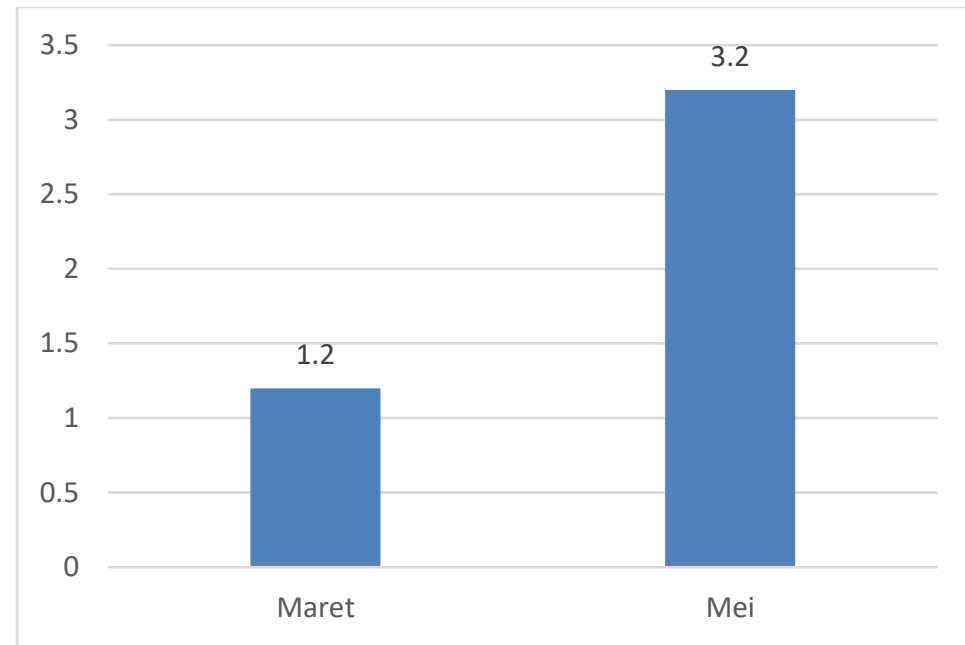

Gambar 3. Kenaikan Angka Kemiskinan

Sumber : Analisis Data Sekunder, 2020

Berdasarkan gambar 3 mengenai kenaikan angka kemiskinan pada bulan maret mengalami tingkat kemiskinan sebesar 1,2\% dan pada bulan mei sebesar 3,2\%. Hal tersebut berarti terdapat kenaikan angka kemiskinansebanyak 2\% yang dialami oleh masyarakat Kecamatan Gatak. Hal tersebut dikarenakan banyak penutupan tempat-tempat ekonomi. Penerapan kebijakan pemerintah pusat yang sebelumnya tentang lockdown diterapkan di kecamatan Gatak dengan menutup sementara waktu pasar Gawok. Tetapi, kebijakan tersebut dinilai kurang efektif karena banyak masyarakat yang mengalami kesulitan perekonomian. Banyak pedagang yang hanya bergantung dengan pekerjaan mereka sebagai pedagang tidak memiliki usaha lain. Di sisi lain, pada mulanya pihak pemerintah daerah menutup semua pasar tradisional untuk mengurangi tertularnya warga Gatak dari Covid-19 selama beberapa hari. Akan tetapi kondisi kesejahteraan dan pendapatan warga menurun sangat derastis karena memang sejatinya warga bergantung dengan berdagang dan petani. Pada akhirnya pihak kecamatan membuka kembali pasar utama yaitu pasar di dekat stasiun Gawok. Sebenarnya penutupan sementara pasar Gawok dimaksudkan untuk mencegah penyebaran virus Covid-19 
yang semakin merebak.

Kebijakan yang diambil setelah peninjauan ulang pihak kecamatan melakukan strerilisasi pasar Gawok dengan penyemprotan cairan disinfektan di seluruh wilayah pasar. Pembukaan kembali pasar Gawok dilakukan untuk membuka kembali lapangan pekerjaan bagi para pedagang, peningkatan kembali pendapatan kas pasar sendiri. Dengan pembukaan ini pemerintah kecamatan Gatak sebelumnya melakukan sosialisasi terhadap masyarakat yang berkunjung maupun berdagang untuk tetap menerapkan protokol kesehatan sesuai anjuran pemerintah. Sampai saat ini pemerintah kecamatan Gatak terus memantau masyarakatnya agar tetap patuh dalam menerapkan protokol kesehatan, melakukan operasi masker setiap 1 minggu sekali.

Pemerintah Kecamatan Gatak juga melakukan penutupan sementara pasar Gawok karena pandemi ini. Kebijakan ini banyak menuai kontra sebenarnya, tetapi mau bagaimana lagi para pedagang hanya bisa pasrah dan menunggu pembukaan pasar kembali. Hal ini dilakukan untuk dilakukan penyemprotan cairan disinfektan di pasar agar tidak terjadi perluasan penyebaran pasien positif Covid-29. Dampak dari pandemi Covid-19 sangat dirasakan masyarakat di bidang ekonomi, pelaku UMKM mengalami penurunan pendapatan, para pedagang mengalami pemerosotan penjualan.

Terkait apa yang terjadi di lapangan pihak terkait mulai melakukan survey apa yang menjadi keluh kesah selama pandemi ini berlangsung. Pemerintah Kecamatan Gatak lalu mengkaji ulang kebijakan yang telah diterapkan demi meningkatkan perekonomian daerah maupun untuk kesejahteraan masyarakat. Tindakan lanjutan yaitu pihak terkait melakukan sosialisasi kepada pengunjung maupun pedagang tentang mekanisme pembukaan kembali pasar Gawok. Sosialisasi untuk tetap menerapkan protokol kesehatan yang telah dianjurkan oleh pemerintah pusat dan tetap menanamkan perilaku disiplin patuh menaati peraturan pada diri sendiri.

Faktor-faktor yang mempengaruhi pendapatan pedagang menurut penelitian yang dilakukan oleh Fatmawati (2014), diantaranya adalah: 1. Modal Modal merupakan faktor yang sangat kuat dengan berhasil atau tidaknya suatu usaha yang telah didirikan. 2. Jam kerja Lama jam kerja yang digunakan seseorang maka akan tinggi tingkat upah atau pendapatan yang diterima oleh seseorang tersebut,dan sebaliknya jika semakin sedikit jumlah jam kerja yang digunakan oleh seseorang maka akan semakin sedikit tingkat upah atau pendapatan yang diterima oleh seseorang tersebut. 3. Pengalaman Salah satu kesalahan fatal yang menyebabkan kegagalan usaha adalah kurangnya pengalaman. Hal ini menunjukkan bahwa pedangang yang 
berpengalaman dapat mempengaruhi keberhasilan usaha, keberhasilan pedagang itu dapat di ukur dari pendapatan yang diperoleh. Dalam hal ini pengalaman diukur berdasarkan lama seorang pedagang tersebut melakukan usaha. Dengan begitu pedagang yang memiliki pengalaman dapat melihat peluang dan celah yang ada dalam masa pandemi seperti penjualan masker dan hand sanitizer yang meningkat sehingga banyak yang menjual produk tersebut.

UMKM berbasis kreativitas harus dikembangkan dengan tata kelola atau kelembagaan dengan mengacu tata kelola kelembagaan di negara maju. Tata kelola kelembagaan meliputi perlindungan hak cipta atas kreatifitas sebagai insentif usaha (Darwanto, 2013). Preswari (2011) mengemukakan pengembangan industri kreatif sampai saat ini belum dapat dimaksimalkan untuk peningkatan perekonomian lokal. Permasalahan yang diperoleh diantaranya yaitu proses produksi yang kurang efisien karena bahan baku berasal dari luar kota. UMKM menjadi penentu ketahanan pendapatan daerah sehingga adanya UMKM sangat membantu daerah dalam mempertahankan eksistensinya. Hal tersebut menjadikan pemerintah daerah harus serius dalam membantu UMKM yang ada terutama di daerah Kecamatan Gatak agar terus konsisten membuat produk dan menjualnya sehingga dampak pandemi tidak menghentikan jalannya UMKM yang ada.

\section{PENUTUP}

Berdasarkan hasil dan pembahasan dalam keterkaitan kebijakan otonomi daerah memiliki pengaruh yang signifikan terhadap penanganan Covid-19. Kebijakan yang diambil harus sesuai dengan keadaan yang ada di lapangan saat ini. Adanya pengkajian ulang memungkinkan penekanan angka penyebaran virus Covid-19. Selain itu, pihak pemerintah Kecamatan Gatak terus melakukan upaya untuk peningkatan perekonomian dan kesejahteraan bagi masyarakat dengan pelonggaran kegiatan di luar rumah dengan tetap menerapkan protokol kesehatan. Kebijakan pemerintah daerah memiliki pengaruh yang signifikan terhadap penanganan Covid-19 dikarenakan adanya potensi potensi pekerja yang berhenti kerja sebanyak $16 \%$ sehingga pihak pemerintah membuka kembali tempat-tempat perekonomian seperti pasar sebagai upaya peningkatan perekonomian dan kesejahteraan masyarakat yang sedang terpuruk dengan tetap menerapkan protokol kesehatan. Perlunya kesadaran masyarakat untuk tetap mematuhi aturan yang ada disaat pandemi seperti ini agar kita terhindar dari virus Covid-19. Tidak egois, jika merasa kurang sehat segera memeriksakan diri ke pelayanan kesehatan terdekat. Ketika pulang dari bepergian jauh harus melakukan karantina mandiri selama batas waktu yang ditentukan. 


\section{DAFTAR PUSTAKA}

Badan Pusat Statistik (BPS). (2011). Statistik Daerah Jawa Tengah 2011: Badan Pusat Statistik Provinsi Jawa Tengah

Ananda, AD. Susilowati, D. (2019). Pengembangan Usaha Mikro Kecil Dan Menengah (UMKM) Berbasis Industri Kreatif Di Kota Malang, Jurnal Ilmu Ekonomi, 10 (10): 120142.

Anggraeni, FD., Hardjanto, I. Hayat, A. (2011). Pengembangan Usaha Mikro, Kecil, Dan Menengah (UMKM) Melalui Fasilitasi Pihak Eksternal Dan Potensi Internal, Jurnal Administrasi Publik (JAP), 1 (6): 1286-1295.

Darwanto. (2013). Peningkatan Daya Saing UMKM Berbasis Inovasi Dan Kreatifitas (Strategi Penguatan Property Right Terhadap Inovasi dan Kreatifitas, Jurnal Bisnis Dan Ekonomi, 20: 142-149.

Engkus, Suparman, Nanang, Sakti, Fajar Tri, Husen, Anwar Saeful. (2020).Covid-19: Kebijakan Mitigasi Penyebaran dan Dampak Sosial Ekonomi di Indonesia http://digilib.uinsgd.ac.id/id/eprint/30820 ( Diakses jam 10:30 WIB tanggal 3 Juli 2020)

Economist Intelligence Unit. (2020). Proyeksi Pertumbuhan Ekonomi Negara. https://katadata.co.id/berita/2020/04/14/ekonomi-di-tengah-pandemi-apakah-akanterjadi-lagi-depresi-besar. Diakses Pada Tanggal 10 Juli 2020.

Iskandar. (2017). Pengaruh Pendapatan Terhadap Pola Pengeluaran Rumah Tangga Miskin Di Kota Langsa, Jurnal Samudra Ekonomika, 1 (2).

Nurwibowo, M. Rahayu, ES. Marwanti, S. (2013). Struktur dan Distribusi Pendapatan Rumah Tangga Serta Strategi Kebijakan Peningkatan Kesejahteraan Petani Jagung Di Lahan Perhutani Di Kecamatan Tanggungharjo Kabupaten Grobogan Provinsi Jawa Tengah, Agribusiness Review, 1 (1): 21-32

Preswari. (2011). Strategi Pengembangan Industri Kreatif Untuk Meningkatkan Daya Saing Pelaku Ekonomi Lokal, Jurnal Aplikasi Managemen, 9: 301-308.

Putri, A.S. (2019). Pengertian Otonomi Daerah. https://www.kompas.com/skola/read/2019/12/16/110000069/pengertian-otonomidaerah (Diakses tanggal 2 Juli 2020).

Rahardja, P., Mandala, M. (2010). Teori Ekonomi Mikro. Jakarta: Lembaga Universitas Indonesia.

Simanjuntak, BA. (2010). Otonomi Daerah, Etnonasionalisme, dan Masa Depan Indonesia; Berapa Persen Lagi Tanah dan Air Nusantara Milik Rakyat?. Jakarta: Yayasan Pustaka 
Obor Indonesia.

World Health Organization (WHO). (2019). Corona Virus Disease 2019. Switzerland.

Yunus, N.R, Rezki, A. (2020). Kebijakan Pemberlakuan Lockdown Sebagai Antipasi Penyebaran Corona Virus Covid-19, Jurnal Sosial \& Budaya Syar-I, 7 (3). 